\title{
Mothers' Hand washing Practice and Diarrhea Cases in Children under Five in Baleendah, Bandung
}

\author{
M. Syafril Firdaus, ${ }^{1}$ Insi Farisa Desy Arya, ${ }^{2}$ Dadang Hudaya Somasetia ${ }^{3}$ \\ ${ }^{1}$ Faculty of Medicine Universitas Padjadjaran, ${ }^{2}$ Department of Public Health Faculty of Medicine \\ Universitas Padjadjaran, ${ }^{3}$ Department of Child Health Faculty of Medicine, Universitas \\ Padjadjaran/Dr. Hasan Sadikin General Hospital Bandung, Indonesia
}

\begin{abstract}
Background: Diarrhea is a disease, especially in children, with high mortality and morbidity rate in developing countries, including Indonesia. Diarrhea can be prevented if people can apply clean and healthy behaviors, especially hand washing. Hand washing is the cheapest, simplest, and the most effective methods for prevention of diarrhea. The objective of this study is to identify the knowledge, attitude, and practice of mothers' hand washing and diarrhea cases in children under five in Baleendah District, Bandung.

Methods: A descriptive study was conducted during September-November 2012 to 210 mothers who had children (ages 12-59 months) in Baleendah using rapid survey technique. The time allocated for each village was adjusted to the population proportion for each region. The data were analyzed using computer and was represented using frequency distribution.

Results: This study showed that the respondents had good level of knowledge and attitude of hand washing ( $83.8 \%$ and $61 \%$, respectively), but only $21 \%$ of the respondents' practices of hand washing was in good level. Most of the respondents did not wash their hands according to the 7 steps of correct hand washing. Moreover the percentage of children with diarrhea in Baleendah was 43.8\% (92 cases) during the study.

Conclusions: There should be dissemination of information about the benefit of washing hands with 7 steps of correct hands washing so that families can practice it and can prevent diarrhea in children under five. [AMJ.2015;2(1):191-8]
\end{abstract}

Keywords: Diarrhea, hand washing, practice, mother

\section{Introduction}

Diarrhea is a major cause of children mortality and morbidity in the developing countries. Based on data from the World Health Organization (WHO) in 2007, it was estimated that every year 100,000 Indonesian children died from diarrhea. In addition, the data from Health Department of Republic of Indonesia in 2000 stated that 300 inhabitants from 1,000 people were affected by diarrhea each year. ${ }^{1,2}$

According to Indonesian Basic Health Research 2007, the leading cause of death on children in Indonesia are diarrhea and Upper Respiratory Infection.3Diarrhea infection is more dominant in babies because their endurance is still weak so they are highly susceptible to viral and bacterial infections that cause diarrhea. According to United Nations International Children Fund (UNICEF) in 2012, it was estimated that each day 2,000 children under five worldwide died from diarrhea. In developing countries, including Indonesia, the baby suffering from diarrhea is more than 12 times per year, making the diarrhea as the causes of death by 15-34\% than other causes of death. Babies who grow up in rural areas are at risk of death 10 times greater than those who grow up in urban areas. ${ }^{4}$

In West Java Province, the incidence of diarrhea occurs up to $10 \%$, surpassing the national average of 9\%. From West Java Provincial Health Office report a few years back, it was stated that Citarum Watershed was given a special attention due to the incidence of diarrhea, one region is Baleendah. ${ }^{5}$

Baleendah District is located in South Bandung with an area of 985,149,5 ha width. Until now, the flood in Citarum River routinely occurs every rainy season. Baleendah and its surrounding areas are often flooded. Diarrhea and respiratory problems often rise due to floods in Baleendah. ${ }^{6}$ According to the Health Center in 2010; diarrheal diseases became the top three diseases for children under five in this district, with a number of case 2,179 patients. $^{7}$

Correspondence: M. yafril Firdaus, Faculty of Medicine, Universitas Padjadjaran, Jalan Raya Bandung-Sumedang Km.21, Jatinangor, Sumedang, Indonesia, Phone: +6285695792727 Email: msyafrilfirdaus@yahoo.com 
In general, clean and healthy lifestyle behaviors in Indonesia are still lacking and it is not to be a community culture. The report from Baleendah Primary Health Care on clean and healthy lifestyle behaviors in 2010, it was shown that from 1,050 households, only 508 that met the clean and healthy lifestyle behaviors standard ${ }^{7}$. The clean and healthy lifestyle behaviors data also support the information that the diarrhea disease will continue occur every year when the public clean and healthy behavior does not change better.

According to WHO, hands are the main lines of germ entry into the body, as the hands often have direct contact with the mouth and nose. Hands can be exposed to germs when we come into contact with the body, others people, animals, or contaminated surfaces. ${ }^{1} \mathrm{WHO}$ shows that washing hands properly with soap at 5 critical times can reduce the incidence of diarrhea by $40 \%$. The five critical times are before eating, after defecation and urination, before holding the child, after cleaning the child, and before preparing food. ${ }^{8}$

Based on the above description, it can be recognized the important roles of mothers who are closest to their children, the five significant times on washing hands with soap, and the high incidence of diarrhea experienced by children under five in Baleendah.Therefore, the author is interested in studying the knowledge, attitude, and practice of mothers' hand washing as well as the occurrence of diarrhea cases in the children under five in Baleendah, Bandung District.

\section{Methods}

A descriptive study was conducted during September-November 2012 to 210 mothers who had children (ages 12-59 months) in Baleendah using rapid survey technique. ${ }^{9}$ The time allocated for each village was adjusted to the population proportion for each region.

Table 1 Questions About Respondents' Hand washing Knowledge (n=210)

\begin{tabular}{|c|c|c|c|c|}
\hline No. & Question & Category & $\begin{array}{c}\text { Number of } \\
\text { Respondents }\end{array}$ & $(\%)$ \\
\hline \multirow[t]{3}{*}{1} & \multirow{3}{*}{$\begin{array}{l}\text { Benefits of hand washing is to } \\
\text { prevent a person affected by } \\
\text { disease }\end{array}$} & Correct answer & 201 & $(95.7)$ \\
\hline & & Wrong answer & 5 & $(2.4)$ \\
\hline & & Do not know & 4 & (1.9) \\
\hline \multirow[t]{3}{*}{2} & \multirow{3}{*}{$\begin{array}{l}\text { Washing hands with soap is not } \\
\text { only carried out when the hand } \\
\text { looks dirty }\end{array}$} & Correct answer & 62 & $(29.5)$ \\
\hline & & Wrong answer & 148 & $(70.5)$ \\
\hline & & Do not know & 0 & $(0.0)$ \\
\hline \multirow[t]{3}{*}{3} & \multirow{3}{*}{$\begin{array}{l}\text { Hands are the main part of the } \\
\text { body as media of germs enter the } \\
\text { body }\end{array}$} & Correct answer & 205 & $(97.6)$ \\
\hline & & Wrong answer & 1 & $(0.5)$ \\
\hline & & Do not know & 4 & (1.9) \\
\hline \multirow[t]{3}{*}{4} & \multirow{3}{*}{$\begin{array}{l}\text { Hand washing should use running } \\
\text { water }\end{array}$} & Correct answer & 58 & $(27.6)$ \\
\hline & & Wrong answer & 151 & (71.9) \\
\hline & & Do not know & 1 & $(0.5)$ \\
\hline \multirow[t]{3}{*}{5} & \multirow{3}{*}{$\begin{array}{l}\text { There are } 7 \text { steps how to wash } \\
\text { hands properly }\end{array}$} & Correct answer & 37 & $(17.6)$ \\
\hline & & Wrong answer & 28 & (13.3 \\
\hline & & Do not know & 145 & $(69.0)$ \\
\hline \multirow[t]{3}{*}{6} & \multirow{3}{*}{$\begin{array}{l}\text { Washing hands with soap is one } \\
\text { of clean and healthy behavior in } \\
\text { households }\end{array}$} & Correct answer & 13 & $(6.2)$ \\
\hline & & Wrong answer & 195 & (92.9) \\
\hline & & Do not know & 2 & $(1.0)$ \\
\hline \multirow[t]{3}{*}{7} & \multirow{3}{*}{$\begin{array}{l}\text { Hand washing is a simple way to } \\
\text { do, inexpensive and can prevent } \\
\text { disease }\end{array}$} & Correct answer & 201 & (95.7) \\
\hline & & Wrong answer & 4 & $(1.9)$ \\
\hline & & Do not know & 5 & $(2.4)$ \\
\hline
\end{tabular}


Table 2 Questions About Respondents' Hand Washing Attitude ( $\mathrm{n}=210)$

\begin{tabular}{|c|c|c|c|c|}
\hline No. & Question & Category & $\begin{array}{l}\text { Number of } \\
\text { Respondents }\end{array}$ & $(\%)$ \\
\hline \multirow[t]{4}{*}{1} & \multirow{4}{*}{$\begin{array}{l}\text { Mothers should wash their hands } \\
\text { with soap before preparing food } \\
\text { for their child, }\end{array}$} & Strongly Agree & 76 & $(36.2)$ \\
\hline & & Agree & 131 & $(62.4)$ \\
\hline & & Disagree & 3 & $(1.4)$ \\
\hline & & Strongly Disagree & 0 & $(0.0)$ \\
\hline \multirow[t]{4}{*}{2} & \multirow{4}{*}{$\begin{array}{l}\text { Mothers should wash their hands } \\
\text { with soap after cleaning their } \\
\text { babies }\end{array}$} & Strongly Agree & 87 & $(41.4)$ \\
\hline & & Agree & 122 & $(58.1)$ \\
\hline & & Disagree & 1 & $(0.5)$ \\
\hline & & Strongly Disagree & 0 & $(0.0)$ \\
\hline \multirow[t]{4}{*}{3} & \multirow{4}{*}{$\begin{array}{l}\text { Mothers do not have to wash their } \\
\text { hands with soap before holding } \\
\text { their child }\end{array}$} & Strongly Agree & 2 & $(1.0)$ \\
\hline & & Agree & 74 & $(35.2)$ \\
\hline & & Disagree & 120 & $(57.1)$ \\
\hline & & Strongly Disagree & 14 & $(6.7)$ \\
\hline \multirow[t]{4}{*}{4} & \multirow[t]{4}{*}{ Hand washing should use soap } & Strongly Agree & 48 & $(22.9)$ \\
\hline & & Agree & 146 & $(69.5)$ \\
\hline & & Disagree & 16 & $(7.6)$ \\
\hline & & Strongly Disagree & 0 & $(0.0)$ \\
\hline \multirow[t]{4}{*}{5} & \multirow{4}{*}{$\begin{array}{l}\text { Hand washing is not always using } \\
\text { the running water }\end{array}$} & Strongly Agree & 13 & $(6.2)$ \\
\hline & & Agree & 65 & $(31.0)$ \\
\hline & & Disagree & 114 & $(54.3)$ \\
\hline & & Strongly Disagree & 18 & $(8.6)$ \\
\hline \multirow[t]{4}{*}{6} & \multirow{4}{*}{$\begin{array}{l}\text { Mothers do not have to wash their } \\
\text { hands with soap before feeding } \\
\text { their child }\end{array}$} & Strongly Agree & 1 & $(0.5)$ \\
\hline & & Agree & 62 & $(29.5)$ \\
\hline & & Disagree & 122 & (58.1) \\
\hline & & Strongly Disagree & 25 & (11.9) \\
\hline \multirow[t]{4}{*}{7} & \multirow{4}{*}{$\begin{array}{l}\text { Mothers should wash their hands } \\
\text { with soap after cleaning the house }\end{array}$} & Strongly Agree & 42 & $(20.0)$ \\
\hline & & Agree & 162 & (77.1) \\
\hline & & Disagree & 6 & (2.9) \\
\hline & & Strongly Disagree & 0 & $(0.0)$ \\
\hline
\end{tabular}

The results showed that Baleendah Village (49 respondents), Andir Village (28 respondents), Manggahang Village (28respondents),Jelekong Village (21 respondents), Wargamekar Village (14 respondents), BojongmalakaVillage (21 respondents), Rancamanyar Village (35 respondets), and Malakasari Village (14 respondents).

The respondents had to meet the inclusion criteria: the child's mother was at home during the study and agreed to participate in filling in validated questionnaire about hand washing.
The questionnaire consisted of 5 questions about characteristic of the respondents, 7 questions about knowledge and attitude respectively, and 9 questions about hand washing practice. The data were analyzed using computer and was represented using frequency distribution.

\section{Results}

Questions about hand washing knowledge 
Table 3 Questions About Respondents' Hand washing Practices ( $n=210)$

\begin{tabular}{|c|c|c|c|c|}
\hline No. & Question & Category & $\begin{array}{l}\text { Number of } \\
\text { Respondents }\end{array}$ & $(\%)$ \\
\hline \multirow[t]{3}{*}{1} & \multirow[t]{3}{*}{ Mother washing hands with soap } & Often & 116 & $(55.2)$ \\
\hline & & Sometimes & 94 & $(44.8)$ \\
\hline & & Never & 0 & $(0.0)$ \\
\hline \multirow[t]{3}{*}{2} & \multirow{3}{*}{$\begin{array}{l}\text { Mother washing hands with } \\
\text { running water frequently }\end{array}$} & Often & 139 & $(66.2)$ \\
\hline & & Sometimes & 66 & $(31.4)$ \\
\hline & & Never & 5 & $(2.4)$ \\
\hline \multirow[t]{3}{*}{3} & \multirow{3}{*}{$\begin{array}{l}\text { Mother did not wash their hands } \\
\text { with soap before handling the } \\
\text { child }\end{array}$} & Often & 18 & $(8.6)$ \\
\hline & & Sometimes & 153 & $(72.9)$ \\
\hline & & Never & 39 & $(18.5)$ \\
\hline \multirow[t]{3}{*}{4} & \multirow{3}{*}{$\begin{array}{l}\text { Mother washing hands before } \\
\text { preparing food for baby }\end{array}$} & Often & 155 & $(73.8)$ \\
\hline & & Sometimes & 53 & $(25.2)$ \\
\hline & & Never & 2 & $(1.0)$ \\
\hline \multirow[t]{3}{*}{5} & \multirow{3}{*}{$\begin{array}{l}\text { Mother drying hands with a clean } \\
\text { towel after washing hands }\end{array}$} & Often & 166 & $(79.0)$ \\
\hline & & Sometimes & 38 & $(18.1)$ \\
\hline & & Never & 6 & $(2.9)$ \\
\hline \multirow[t]{3}{*}{6} & \multirow{3}{*}{$\begin{array}{l}\text { Mother washing hands after } \\
\text { cleaning the baby }\end{array}$} & Often & 206 & $(98.1)$ \\
\hline & & Sometimes & 4 & $(1.9)$ \\
\hline & & Never & 0 & $(0.0)$ \\
\hline \multirow[t]{3}{*}{7} & \multirow{3}{*}{$\begin{array}{l}\text { Mother did not wash hands before } \\
\text { feeding the child }\end{array}$} & Often & 23 & $(11.0)$ \\
\hline & & Sometimes & 121 & $(57.6)$ \\
\hline & & Never & 66 & $(31.4)$ \\
\hline \multirow[t]{3}{*}{8} & \multirow{3}{*}{$\begin{array}{l}\text { Mother did not wash hands after } \\
\text { cleaning the house }\end{array}$} & Often & 21 & $(10.0)$ \\
\hline & & Sometimes & 35 & $(16.7)$ \\
\hline & & Never & 154 & (73.3) \\
\hline \multirow[t]{3}{*}{9} & \multirow{3}{*}{$\begin{array}{l}\text { Mother washing hands with } 7 \\
\text { steps how to wash hands well and } \\
\text { correctly }\end{array}$} & Often & 8 & (3.8) \\
\hline & & Sometimes & 9 & $(4.3)$ \\
\hline & & Never & 193 & (91.9) \\
\hline
\end{tabular}

consist of the benefit, ways of using soap, running water, washing hands properly, and preventing the disease. Most of the respondents could answer the question about the benefit of hand washing $(95.7 \%)$. Hands are the main part of the body as media of germs to enter the body $(97.6 \%)$. Hand washing is a simple way to do, inexpensive and can prevent disease $(95.7 \%)$. The majority of mothers $(69 \%)$ did not know about the 7 steps of how to wash hands properly. The rest of the questions were answered wrong (Table 1).

For the question about respondents hand washing attitude, most of the respondents was agree about washing with soap before preparing food for their child $(62,4 \%)$, after cleaning their babies (58.1\%), and after cleaning the house $(77.1 \%)$. Therefore, the respondents were disagree with the question about do not have to wash their hands with soap before holding their child (57.1\%), hand washing is not always using the running water (54.3\%), do not have to wash their hands with soap before feeding their child (54.3\%) (Table 2).

For the level of hand washing practices, from 210 respondents, 193 mothers (91.9\%) said they never washed their hands by 
Table 4 Description about Respondents' Hand washing Knowledge, Attitude, and Practice $(n=210)$

\begin{tabular}{llccc}
\hline No. & Question & Category & $\begin{array}{c}\text { Number of } \\
\text { Respondents }\end{array}$ & (\%) \\
\hline 1 & \multirow{3}{*}{ Knowledge } & Good & 176 & $(83.8)$ \\
& & Fair & 34 & $(16.2)$ \\
& & Poor & 0 & $(0.0)$ \\
& \multirow{3}{*}{ Attitude } & Good & 128 & $(61)$ \\
& & Fair & 22 & $(10)$ \\
3 & \multirow{3}{*}{ Practice } & Poor & 60 & $(29)$ \\
& & Good & 44 & $(21.0)$ \\
& & Fair & 117 & $(55.7)$ \\
& & Poor & 49 & $(23.3)$ \\
\hline
\end{tabular}

following the 7 steps of how to wash hands properly (Table 3 ).

Knowledge, attitude, and practice are essential in any clean and healthy behaviors. Overall, a description about knowledge and attitude of the mothers regarding the importance of hand washing was in good category (83.8\% and 61\%), meanwhile for the description about respondent's practice was in fair level (55.7\%) (Table 4).

According to sociodemographic characteristics and affordability, it can be discovered that from 210 respondents, 92 of them had their children under five with diarrhea in the last month (Table 5). Based on the age group of children, the incidence of diarrhea is mostly experienced in the age group of 12-23 months, amounting to $58.7 \%$, and at least in the age group of 48-59 months by $8.7 \%$.

\section{Discussions}

Based on the study result, a description on knowledge level of the mothers regarding the importance of hand washing is in good level. This evident is derived from the study showing that the average level of respondent knowledge is in both categories (83.8\%). However, the existing questionnaire questions, the question number 5 showed that the majority of mothers $(69 \%)$ did not know about the 7 steps of how to wash hands properly. This suggests that mothers understand the importance of washing hands with soap as one way of preventing the entry of germs into the body, but they do not know how to wash the hands properly. These results are similar to studies in other villages, e.g. Hegarmanah and Sayang Villages, Jatinangor District, it was stated that $92.9 \%$ of women did not know about the 7 steps how to wash hands well and correctly. ${ }^{10}$

For the level of attitudes, the results of this study also showed that still there were mothers who had a relatively less stance on the importance of hand washing (29\%). A study conducted in Hegarmanah and Sayang Villages, Jatinangor District, showed as much as $78.1 \%$ of women were categorized in good level. ${ }^{10}$ According to Bloom, the attitude factors become the major influence on people's health status. Maternal attitudes in health is crucial to the health status of the families, including their children. This is because the mothers usually become the direct caregiver for the child so that more interaction occurs. ${ }^{11}$

For the level of hand washing practices, most mothers were in the category of enough $(55.7 \%)$. This indicates that most mothers do not have good knowledge about hand washing practice. According to WHO report, people who do not have access to soap will be difficult to implement washing hands with soap. ${ }^{12}$ However, the absence of soap is not a barrier to washing hands with soap practice in this study. They have reason that the hand still looks clean. Therefore they assumed that washing hands was a very time consuming, moreover the lack of nearby places to wash hands, such as a sink, had become the reason for the low level of the respondents' hand washing practices in this study. According to the study performed in Hegarmanah and Sayang Village, Jatinangor District, the study showed that as much as $82.4 \%$ of women were categorized in poor level. ${ }^{10}$

It is also worth to highlight the questionnaire 
Table 5 Diarrhea Cases in Children Under Five in The Last Month According to Sociodemographic Characteristics and Affordability

\begin{tabular}{|c|c|c|c|c|}
\hline \multirow{3}{*}{ Characteristics } & \multicolumn{4}{|c|}{ Diarrhea } \\
\hline & \multicolumn{2}{|c|}{ Yes } & \multicolumn{2}{|c|}{ No } \\
\hline & $\mathbf{n}$ & $\%$ & $\mathbf{n}$ & $\%$ \\
\hline \multicolumn{5}{|l|}{ Mother's Education } \\
\hline Not Finished elementary school & 0 & $(.0)$ & 1 & $(100.0)$ \\
\hline elementary school Graduates & 26 & $(55.3)$ & 21 & $(44.7)$ \\
\hline junior high school Graduate & 41 & $(44.6)$ & 51 & $(55.4)$ \\
\hline Senior high school Graduate & 20 & $(31.7)$ & 43 & $(68.3)$ \\
\hline Colleges Graduate & 5 & $(71.4)$ & 2 & $(28.6)$ \\
\hline Total & 92 & $(43.8)$ & 118 & $(56.2)$ \\
\hline \multicolumn{5}{|l|}{ Family Income } \\
\hline$<$ regional minimum wage (UMR) & 57 & $(44.9)$ & 70 & $(55.1)$ \\
\hline >regional minimum wage (UMR) & 35 & $(42.2)$ & 48 & $(57.8)$ \\
\hline Total & 92 & $(43.8)$ & 118 & $(56.2)$ \\
\hline \multicolumn{5}{|l|}{ Children Age (months) } \\
\hline $12-23$ & 54 & $(55.7)$ & 43 & $(44.3)$ \\
\hline $24-35$ & 21 & $(42.0)$ & 29 & $(58.0)$ \\
\hline $36-47$ & 9 & $(24.3)$ & 28 & $(75.7)$ \\
\hline $48-59$ & 8 & $(30.8)$ & 18 & $(69.2)$ \\
\hline Total & 92 & $(43.8)$ & 118 & $(56.2)$ \\
\hline \multicolumn{5}{|l|}{ Children Sex } \\
\hline Male & 48 & $(42.5)$ & 65 & $(57.5)$ \\
\hline Female & 44 & $(45.4)$ & 54 & $(54.6)$ \\
\hline Total & 92 & $(43.8)$ & 118 & $(56.2)$ \\
\hline
\end{tabular}

results about 7 hand washing practices steps that were performed well and correctly. From 210 respondents, 193 mothers $(91.9 \%)$ said they never washed their hands by following the 7 steps of how to wash hands properly. It is caused by mothers' lack of knowledge about good hand washing, given that the maternal ignorance about the 7 steps reaching $69 \%$. These results are similar to studies in Karachi, Pakistan, which also stated that as many as $84 \%$ women never washed their hands with the 7 steps. $^{13}$

Overall, the study in Indonesia showed that people know many germs on the hands. However, hand washing behavior has not become a daily habit, especially in the five critical times to wash hands: before eating, after defecation and urination, before holding the child, after cleaning the child, and before preparing food. There were only about $0-34 \%$ who washed hands at the critical times. ${ }^{14,15}$

Theresultsare notmuch differentfrom other studies on developing countries. According to The Global Public Private Partnership for Hand Washing, hand washing habits in India reached 34\%, Ghana 3\%, Senegal 31\%, Nigeria $10 \%$, and Burkina Faso $13 \% .^{12}$

Knowledge about health is the basis for behavior change, yet there is possibility of someone not to necessarily act on the knowledge base owned. ${ }^{16}$ According to the research in 11 major countries on hand washing behavior, there are three factors affecting the hand washing behavior: planned activity, motivation to conduct, and health behavior habits. ${ }^{17}$

Based on the study result, the incidence of children under five with diarrhea in the last month were 210 respondents and 92 (43.8\%) mother had children under five with diarrhea 
in the last month. The other studies conducted in the slums of North Jakarta with household survey technique showed that children under five with diarrhea in the last month reached $13 \%$ children. ${ }^{18}$ These results is in contrast with Baleendah District although both areas are flooded areas.

Based on the age group of children, the incidence of diarrhea is mostly experienced in the age group of 12-23 months, amounting to $58.7 \%$, and at least in the age group of 48-59 months by $8.7 \%$. These results are consistent with the research in Semarang. The research showed that the incidence of diarrhea in children under five in the age group $<24$ months was (58.68\%), followed by age group 24-36 months with (24.65\%) and the least in group aged of 37-60 months with $(16.67 \%)^{16}$. Similar results were also shown by the study of Health Primary Center Tetehosi Foa, District Gido, Niasa Regency, North Sumatra ${ }^{19}$, stating that the largest proportion of children under five with diarrhea were in the age group of 1-3 years, which was equal to $46.8 \%$. All cases of diarrhea in children under five in Baleendah were acute diarrhea, the diarrhea that occurred with the duration of no more than 14 days.

As conclusion, there should be information dissemination on the benefit of washing hands with 7 steps of correct hands washing through a simulation. In addition, the collaboration between health primary center and integrated health cares in the local community should also be made to promote the clean and healthy lifestyle behaviors campaign in the household. Therefore, the families can practice the clean and healthy lifestyle behaviors to prevent diarrhea in children under five, especially with washing hands with soap.

\section{References}

1. World Health Organization. Diarrhoea: why children are still dying and what could be done. Geneva: World Health Organization; 2009.

2. West Java Provincial Health Office. PHBS di sekolah. 2006. [Cited 2012 April 16]. Available from: http://www.diskes. jabarprov.go.id/index.php? $\bmod =\&$ idMenu $\mathrm{K}=50$ \&iMenuTab=52.

3. Indonesian Council for Health Research and Development. Riset kesehatan dasar Provinsi Jawa Barat. Jakarta: Health Department of Indonesian Republic; 2008.

4. Health Department of Indonesian Republic. Profil kesehatan Indonesia tahun 2008. 2008. [Cited 2012 April 20]. Available from: http://www.depkes. go.id/downloads/publikasi/Profil\%20 Kesehatan\%20Indonesia\%202008.pdf.

5. West Java Provincial Health Office. Laporan hasil riset kesehatan dasar Provinsi Jawa Barat tahun 2007. 2007. [Cited 2012 April 20]. Available from: http://www.diskes. jabarprov.go.id/index.php? $\bmod =$ pubDow nload\&idMenuKiri=9\&idKategori=7.

6. Imanuel NS. Baleendah, Bandung. 2012 [Cited 2012 April 25]. Available from at: http://id.wikipedia.org/wiki/Baleendah_ Bandung.

7. Bandung District Health Office. Buku laporan tahunan puskesmas Baleendah 2011. Bandung: Bandung District Health Office; 2012.

8. Health Department of Indonesian Republic. Panduan penyelenggaraan hari cuci tangan pakai sabun sedunia (HCTPS). 2nd ed. Jakarta; 2009.[Cited 2012 April 25]. Available from: http://digilib-ampl. net/file/pdf/panduan_HCTPS_09.pdf.

9. Sabri L, Ariawan I, Hadi EN, Trihandini I, Prasetyo S. Aplikasi survei cepat. 2nd ed. Depok: Fakultas Kedokteran Universitas Indonesia dan Pusat Data Kesehatan Departemen Kesehatan; 1996.

10. Ikhsanun KP. Gambaran pengetahuan, sikap, dan perilaku ibu rumah tangga tentang cuci tangan di Desa Hegarmanah dan Desa Sayang Kecamatan Jatinangor tahun 2011 [minor-thesis]. Bandung: Universitas Padjadjaran; 2012.

11. Notoatmodjo S. Konsep perilaku kesehatan, promosi kesehatan teori dan aplikasi. Jakarta: PT. Rineka Cipta; 2010.

12. Mach M. Fighting child mortality through handwashing. 2012. [Cited 2012 December 5]; Available from: http://mirayafm.net/ index.php/special-reports/9932-fightingchild-mortality-through-provision-ofsafe-water.

13. Sherwani SK, Bashir A, Ahmed H, Alam SI. Knowledge, attitude, and practices of washing hands among mothers in Karachi, Pakistan. Fuuast J Biol. 2011;1(1):103-6.

14. Sutriyanto E. Pentingnya cuci tangan pakai sabun. 2011. [Cited 2012 December 5]; Available at: http://www.tribunnews. com $/ 2011 / 10 / 14 /$ pentingnya-cucitangan-pakai-sabun.

15. Team CCiSC. WHO guidelines on hand hygiene in health care: a summary 2009. [downloaded in 5 December 2012];Available at:http:// who.int/gpsc/5 may/tools/who_ 
guidelinehandhygiene_summary.pdf.

16. Sinthamurniwaty. Faktor-faktor risiko kejadian diare akut pada balita [minorthesis]. Semarang: Universitas Diponegoro; 2006.

17. Curtis VA, Danquah LO, AungerRV. Planned, motivated and habitual hygiene behaviour: an eleven country review. Health Educ Res. 2009;24(4):655-73.
18. Simanjuntak CH. Diarrhoea episodes and treatment-seeking behaviour in a slum area of North Jakarta, Indonesia. J Health Popul Nutr. 2004:8(2):83-92.

19. Mendrofa K. Karakteristik balita penderita diare yang berobat di Puskesmas Tetehosi Foa, Kecamatan Gido, Kabupaten Niasa tahun 2005 [minor-thesis]. Medan: Universitas Sumatera Utara; 2006. 